\title{
3D models related to the publication: New information on the braincase and endocranial morphology of the Late Triassic neotheropod Zupaysaurus rougieri using Computed Tomography data
}

\author{
Paulina-Carabajal Ariana ${ }^{1 *}$, Ezcurra Martín ${ }^{2}$, Novas Fernando ${ }^{3}$ \\ ${ }^{1}$ INIBIOMA, Universidad Nacional del Comahue, CONICET, Quintral 1250, San Carlos de Bariloche (8400), Argentina. \\ ${ }^{2}$ Sección Paleontología de Vertebrados, CONICET-Museo Argentino de Ciencias Naturales "Bernardino Rivadavia", Avenida Ángel Gallardo 470 \\ (C1405DJR), Buenos Aires, Argentina \\ ${ }^{3}$ Laboratorio de Anatomía Comparada y Evolución de los Vertebrados, CONICET-Museo Argentino de Ciencias Naturales "Bernardino Rivadavia", \\ Avenida Ángel Gallardo 470 (C1405DJR), Buenos Aires, Argentina. \\ ${ }^{*}$ Corresponding author: a.paulinacarabajal@conicet.gov.ar
}

\begin{abstract}
The present 3D Dataset contains the 3D models analyzed in the following publication: Paulina-Carabajal, A., Ezcurra, M., Novas, F., 2019. New information on the braincase and endocranial morphology of the Late Triassic neotheropod Zupaysaurus rougieri using Computed Tomography data. Journal of Vertebrate Paleontology. https: //doi.org/10.1080/02724634.2019.1630421
\end{abstract}

Keywords: Braincase, Paleoneurology, South America, Theropoda

Submitted:2019-07-12, published online:2019-08-26. https://doi.org/10.18563/journal.m3.96

$\begin{array}{llc}\text { Inv. nr } & \text { Taxon } & \begin{array}{c}\text { Description } \\ \text { PULR076 }\end{array} \\ \text { Zupaysaurus rougieri } & \begin{array}{c}\text { Skull, braincase and } \\ \text { cranial endocast. }\end{array}\end{array}$

Table 1. Involved specimen (collection: Universidad Nacional de La Rioja, La Rioja, Argentina)

\section{INTRODUCTION}

Zupaysaurus rougieri was a neotheropod from the late Triassic of Argentina. The skull was preserved complete and articulated (Arcucci and Coria, 2003; Ezcurra, 2007); Using CT scan data, the braincase was virtually extracted allowing the study of its morphology. Further, the cranial endocast and partially preserved inner ear, represent the oldest anatomical information for a representative of the clade Neotheropoda (Paulina-Carabajal et al., 2019) (Fig. 1 and table 1).

\section{METHODS}

The 3D surfaces of the skull, braincase, brain and inner ear were extracted using Materialise Mimics 18.0 using the segmentation threshold selection tool. The 3D surface models are provided in .ply format, and can therefore be opened with a wide range of freeware.

\section{ACKNOWLEDGEMENTS}

Grant sponsors: 1. Agencia Nacional de Promoción Científica y Tecnológica, 1. PICT-2016-0481 to AP-C, PICT 2011-1652 to FEN.

\section{BIBLIOGRAPHY}

Arcucci, A., R. A. Coria., 2003. A new Triassic dinosaur. Ameghiniana 40, 217-228.

Ezcurra, M. D. 2007. The cranial anatomy of the coelophysoid theropod Zupaysaurus rougieri from the Upper Triassic of Argentina. Historical Biology 19, 185-202. https://doi.org/10. 1080/08912960600861467

Paulina-Carabajal, A., Ezcurra, M., Novas, F. E., 2019. New information on the braincase and endocranial morphology of the Late Triassic neotheropod Zupaysaurus rougieri using Computed Tomography data. Journal of Vertebrate Paleontology. https://doi.org/10.1080/02724634.2019.1630421 

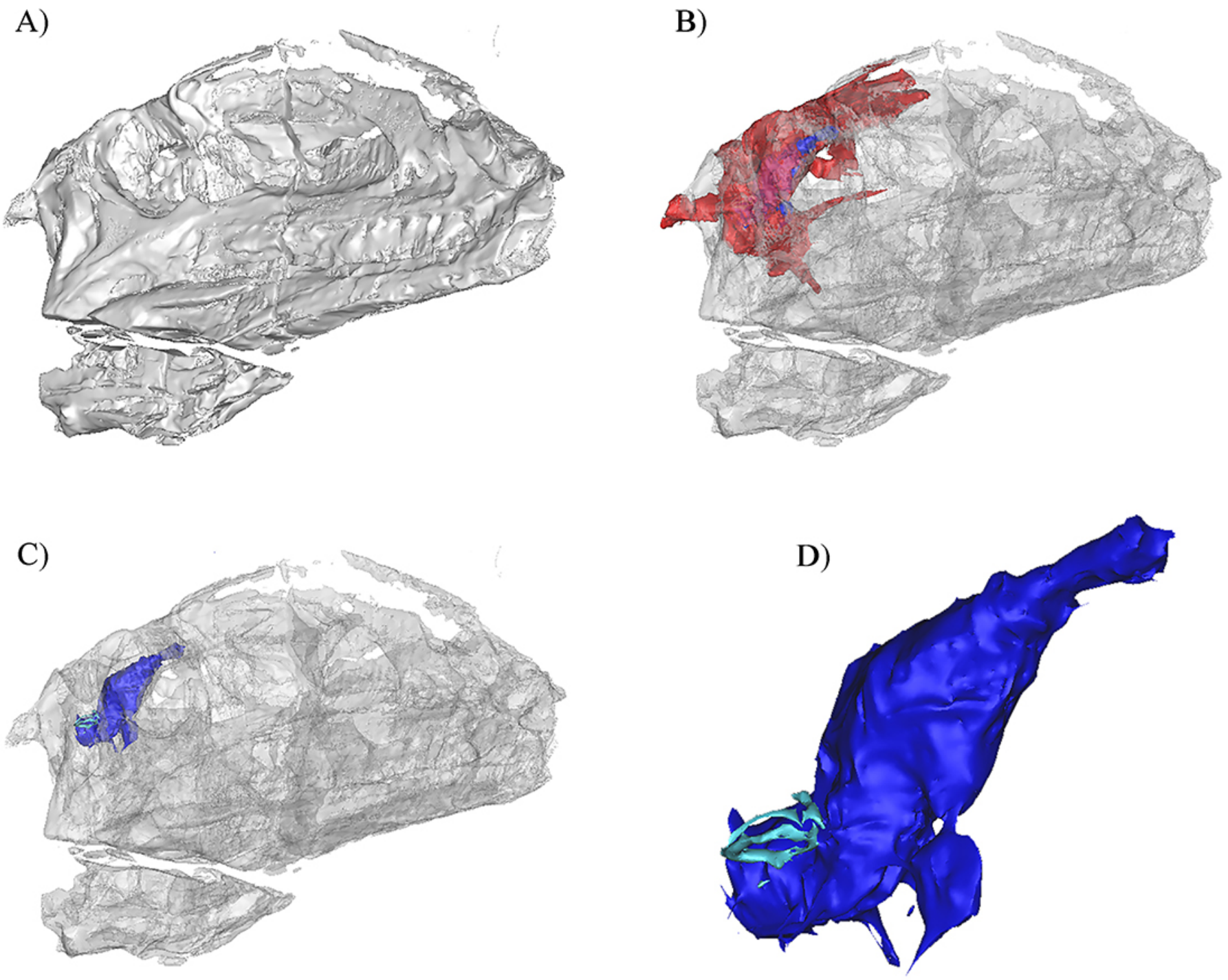

Figure 1. Skull of the neotheropod dinosaur Zupaysaurus rougieri (PULR 076; Universidad Nacional de La Rioja, La Rioja, Argentina) in anterolateral right view. A) bone solid, B) skull bones rendered semi-transparent to allow observation of the braincase, C) skull bones rendered semi-transparent to allow observation of the brain, D) detail of the brain and partial right inner ear (not to scale). Gray, skull bones; red, braincase; blue, cranial endocast, light-blue, inner ear. 